\title{
Cyanobacterial removal by a red soil-based flocculant and its effect on zooplankton: an experiment with deep enclosures in a tropical reservoir in China
}

\author{
Liang Peng ${ }^{1} \cdot$ Lamei Lei $^{1} \cdot$ Lijuan Xiao $^{1} \cdot$ Boping Han ${ }^{1,2}$ (D) \\ Received: 14 September 2017 / Accepted: 18 June 2018 / Published online: 4 June 2018 \\ (C) The Author(s) 2018
}

\begin{abstract}
As one kind of cheap, environmentally-friendly and efficient treatment materials for direct control of cyanobacterial blooms, modified clays have been widely concerned. The present study evaluated cyanobaterial removal by a red soil-based flocculant (RSBF) with a large enclosure experiment in a tropical mesotrophic reservoir, in which phytoplankton community was dominated by Microcystis spp. and Anabaena spp. The flocculant was composed of red soil, chitosan and $\mathrm{FeCl}_{3}$. Twelve enclosures were used in the experiment: three replicates for each of one control and three treatments $\mathrm{RSBF}_{15}\left(15 \mathrm{mg} \mathrm{FeCl}_{3} \mathrm{l}^{-1}\right), \mathrm{RSBF}_{25}$ (25 $\mathrm{mg} \mathrm{FeCl}_{3} \mathrm{l}^{-1}$ ), and $\mathrm{RSBF}_{35}\left(35 \mathrm{mg} \mathrm{FeCl}_{3} \mathrm{l}^{-1}\right)$. The results showed that the red soil-based flocculant can significantly remove cyanobacterial biomass and reduce concentrations of nutrients including total nitrogen, nitrate, ammonia, total phosphorus, and orthophosphate. Biomass of Microcystis spp. and Anabaena spp. was reduced more efficiently (95\%) than other filamentous cyanobacteria $(50 \%)$. In the $\mathrm{RSBF}_{15}$ treatment, phytoplankton biomass recovered to the level of the control group after 12 days and cyanobacteria quickly dominated. Phytoplankton biomass in the $\mathrm{RSBF}_{25}$ treatment also recovered after 12 days, but green algae co-dominated with cyanobacteria. A much later recovery of phytoplankton until the day of 28 was observed under RSBF 35 treatment, and cyanobacteria did no longer dominate the phytoplankton community. The application of red soil-based flocculant greatly reduces zooplankton, especially rotifers, however, Copepods and Cladocera recovered fast. Generally, the red soil-based flocculant can be effective for urgent treatments at local scales in cyanobacteria dominating systems.
\end{abstract}

Keywords Red soil-based flocculant $\cdot$ Cyanobacteria $\cdot$ Removal $\cdot$ Recovery $\cdot$ Zooplankton $\cdot$ Enclosure

\section{Introduction}

Cyanobacterial blooms with eutrophication are increasing throughout the world because of deteriorating global environment (Codd 2000; de Figueiredo et al. 2004; O'Neil et al. 2012; Jeppesen et al. 2017). Cyanobacterial blooms and cyanotoxins pose high risks to human health and have triggered

Responsible editor: Vitor Manuel Oliveira Vasconcelos

Boping Han

tbphan@126.com; tbphan@jnu.edu.cn

1 Institute of Hydrobiology, Jinan University, Guangzhou 510632, China

2 Engineering Research Center of Tropical and Subtropical Aquatic Ecological Engineering, Ministry of Education, Guangzhou 510632, China a series of problems for aquatic ecosystems through such processes as diminishing dissolved oxygen, decreasing water transparency, reducing biodiversity, and producing toxins and offodors (Lindholm et al. 1989; van Apeldoorn et al. 2007; Dash et al. 2015). Not surprisingly, controlling cyanobacterial blooms have become one of the leading issues for ecosystem management (Hrudey et al. 1999; Paerl et al. 2011). Negative impacts of cyanobacterial blooms on aquatic ecosystems have led to suggestions of an upper limit of algal cells in the management of lakes and reservoirs, especially those for drinking water supply (Qin et al. 2010; Newcombe et al. 2010). The World Health Organization also proposed an alert level for drinking water (Chorus and Bartman 1999).

Direct control measures of cyanobacterial biomass are usually grouped into three categories: (1) physical materials such as UV light, ultrasonication, and filtration (Lawton et al. 1998; Rajasekhar et al. 2012); (2) chemical coagulation, flocculation, and algicide (Jeune et al. 2006; Teixeira and Rosa 2006); and (3) 
biological inhibition and degradation using microorganisms, grazers, and extractions from organisms (Hunt and Matveev 2005; Ji et al. 2009; Combes et al. 2013). Flocculants combined with various substances have been widely used as an efficient, rapid and low cost method of controlling cyanobacterial density in natural water (Sridhar et al. 1988; Sengco et al. 2001; Beaulieu et al. 2005; Lee et al. 2008). Materials such as metal ions, plant seeds, and synthetic organic matter are able to significantly improve the efficiency of flocculants in cyanobacteria removal (Chow et al. 1998; Robb et al. 2003; Liu et al. 2010; Teixeira et al. 2010; Nishi et al. 2012). Clays have different removal efficiency, which depending on cyanobacterial species and phytoplankton communities (Avnimelech et al. 1982; Pan et al. 2006; Verspagen et al. 2006; Anderson 2009; Lürling and Faassen 2012; Vandamme et al. 2013). Effects of flocculation on aquatic animals and macrophyte in water bodies have been investigated (Lewis et al. 2003; Akeprathumchai et al. 2004; Archambault et al. 2004; Lee et al. 2008; Seo et al. 2008). Some modified clays show low toxicity to cladocera and copepods, while Lanthanum addition was found to be chronically toxic to Daphnia spp. (Stauber 2000). The $\mathrm{EC}_{50}$ (half maximal effective concentration) of a modified clay on the population growth of rotifer is suggested by van Oosterhout and Lürling (2013) to be suitable for field application. However, low concentration clay has less effect on Daphnia, although the animals became smaller, matured later, and reproduced less as lanthanum increases, resulting in lower population growth rates in the presence of phosphate (Lürling and Tolman 2010). Clay flocculation is thought to be helpful for the restoration of submerged macrophyte with improved water quality (Boustany 2003).

In China, cyanobacterial blooms caused by Microcystis, Anabaena, Aphanizomenon, and Cylindrospermopsis are a common occurrence in many lakes and reservoirs (Qin 2002; Cai et al. 2012; Lei et al. 2012). The blooms are mainly observed in the dry season from late autumn to spring in southern China, a phenomenon quite different from that in the temperate zone. The absence of cyanobacterial blooms in the wet (monsoonal) season is usually attributed to high flush rate, which strongly reduces phytoplankton density. However, high amounts of suspended inorganic particles washed from the red soil watersheds may also play an important role in flocculation. Wang et al. (2012) found a significant negative relationship between particle concentration and phytoplankton density in a large canyon reservoir. Flushing water with clay is effective at mitigating cyanobacterial growth and at suppressing cyanobacterial blooms (Mitrovic et al. 2011). Red soils are rich in iron in southern China (Xu et al. 2006) and contribute suspended inorganic particles in watersheds, which appear effective in flocculation. Xiao et al. (2007) and Liu (2016) reported modified red soil with iron is more efficient reducing cyanobacterial biomass than natural red soil. In practical application, we add chitosan as an auxiliary coagulant to enhance flocculation as early suggestion (e.g., Pan et al.
2011). However, the removal capacity of such new modified red soil (red soil-based flocculant, RSBF) has not been quantitatively evaluated, and there is a little information regarding the possible effect on other phytoplankton species and zooplankton. In the present study, we applied one of the new modified red soils in a large enclosure experimental system to test (1) the removal efficiency of different cyanobacterial species and its influence on phytoplankton community, (2) the recovery time of cyanobacteria, and (3) the possible negative impact on zooplankton community.

\section{Materials and methods}

Twelve enclosures were installed in the tropical mesotrophic Dashahe Reservoir (N 22.52', E 112.42') in southern China (Fig. 1). During the experimental period, water temperature ranged from 28.4 to $30.4{ }^{\circ} \mathrm{C}$, $\mathrm{pH}$ value ranged from 6.2 to 7.8 , turbidity ranged from 241.2 to 335.4 NTU, and salinity was stable at 0.04 . Each enclosure has a volume of $340 \mathrm{~m}^{3}(6 \mathrm{~m}$ diameter, $12 \mathrm{~m}$ deep). The enclosures were made of polypropylene, and were open at the top and bottom. The upper mouth was framed with a steel rim fixed with a floating system, which kept the top of enclosure out of the water $(0.5 \mathrm{~m}$ above the water surface) and the enclosures in upright position. The end rim of each enclosure was inserted into the sediment by a weighed stone line. There was no water exchange between the enclosures and the surrounding water except that from the sediment.

Ferric trichloride and chitosan of analytical pure were the production from Sinopharm Group CO.LTD (China). Local red soil, ferric trichloride, and chitosan were screened with a $0.85-\mathrm{mm}$ mesh sieve and mixed together. There were three experimental treatments each with a different combination of concentrations of RSBF (termed $\mathrm{RSBF}_{15}, \mathrm{RSBF}_{25}$, and $\mathrm{RSBF}_{35}$ Table 1). Each treatment plus the control have three replicates. Water samples were collected from each enclosure every 4 days for nutrient measurement and phytoplankton and zooplankton species counts. The RSBF was added only once into the nine treatment enclosures just after the first sampling. The experiment started on August 25, 2008 and ended on October 4, 2008.

Temperature and $\mathrm{pH}$ were measured with a portable YSI at a depth of $0.5 \mathrm{~m}$ below the water surface. Water transparency in Secchi depth (SD) was measured with Secchi disk. Nutrient concentrations were measured following the national standard methods published by Chinese EPA (China National Standards 1987a, b, 1989a, b). Chlorophyll $a$ was extracted with $90 \%$ acetone and then determined with a spectrophotometric method (Lin et al. 2005). Phytoplankton was collected from the surface to $0.5 \mathrm{~m}$ depth of the water column and preserved with formalin solution $(0.5 \%)$. Phytoplankton samples were identified under inverted microscopy using Utermöhl chambers according to Lund et al. (1958) to the species level. Biovolume of each species was calculated based 

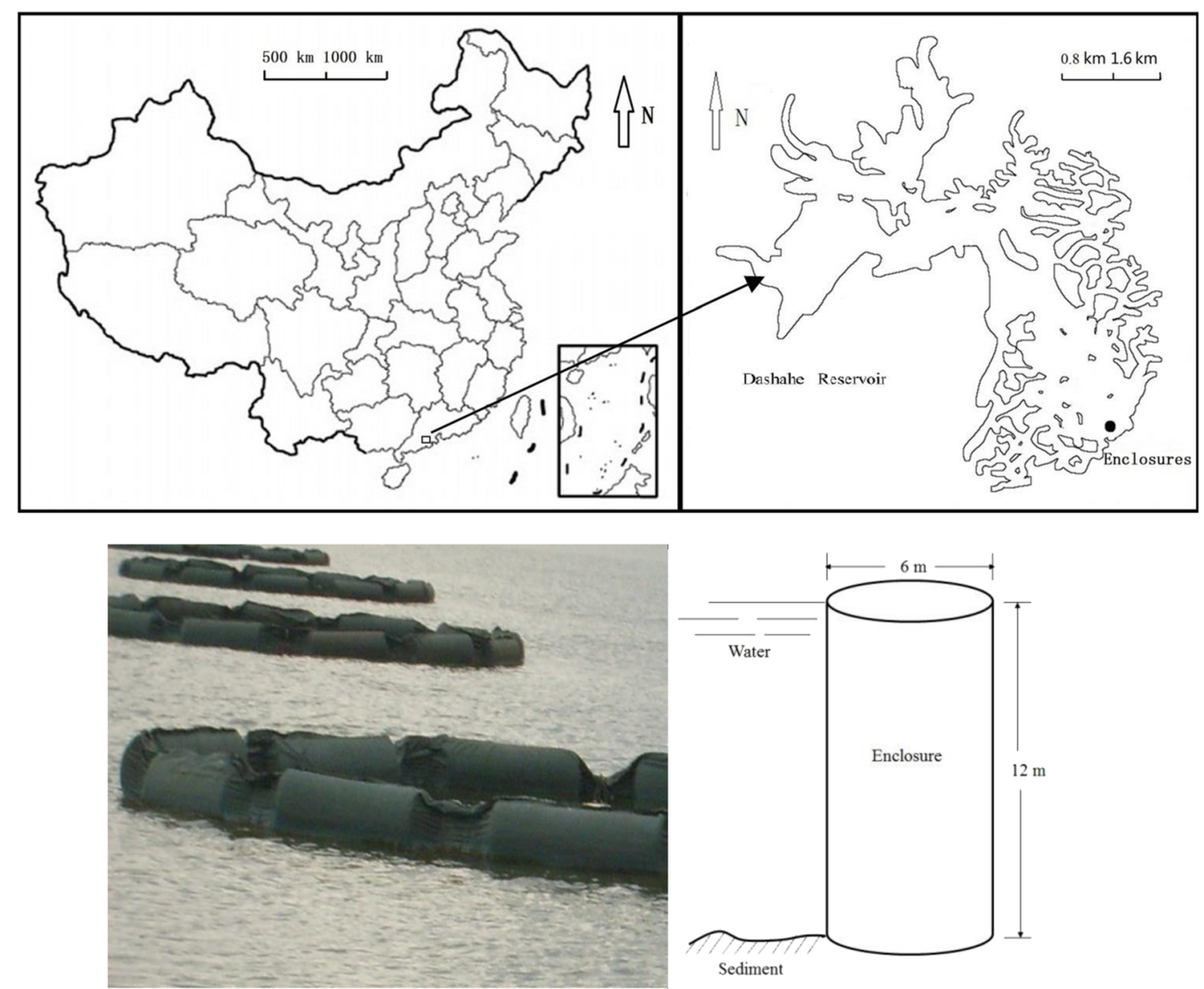

Fig. 1 Location and diagram of enclosures in the studied reservoir: Dashahe reservoir, southern China

on the morphology of cells according to Hillebrand et al. (1999). Zooplankton was sampled with a 5-L sampler at 1-m interval from a depth of 0.5 to $12 \mathrm{~m}$ (near the bottom). Zooplankton was gathered and filtered with a plankton net (mesh size $38 \mu \mathrm{m}$ ), then stored in 5\% formalin solution. Zooplankton was sampled three times during the experimental period - the first day, day 10 , and day 20 , and identified to species and counted for abundance under the microscope (Koste 1978; Shen and Song 1979; Korovchinsky 1992).

For three treatments and the control, the comparison between treatments was analyzed by one-way ANOVA. Two-way mixed repeated measure ANOVA in generalized linear model was also

Table 1 Final concentration of the red soil-based flocculant (RSBF) used in the experiment

\begin{tabular}{llll}
\hline & $\mathrm{FeCl}_{3}\left(\mathrm{mg} \mathrm{l}^{-1}\right)$ & Chitosan $\left(\mathrm{mg} \mathrm{l}^{-1}\right)$ & $\begin{array}{l}\text { Local red } \\
\text { soil }\left(\mathrm{g} \mathrm{l}^{-1}\right)\end{array}$ \\
\hline Control & 0 & 0 & 0 \\
$\mathrm{RSBF}_{15}$ & 15 & 2.5 & 0.13 \\
$\mathrm{RSBF}_{25}$ & 25 & 4.2 & 0.17 \\
$\mathrm{RSBF}_{35}$ & 35 & 5.8 & 0.23 \\
\hline
\end{tabular}

used for time series observation. We first detected the variances of the differences between all combinations of groups of withinsubjects factors by the Mauchly's tests of sphericity. If there is no homogeneity of variances, the correction by adjustment of freedom degrees was applied. The treatments were compared by post hoc tests. Bonferroni correction was used to compare main effects. As flocculant was added only once, the phytoplankton and zooplankton started to recover 1 week later, more groups of within-subjects will reduce the difference between the time and the treatment. Thus, we used both ANOVA and repeated measure ANOVA to detect the effect of the flocculant in the treatments. An SPSS statistical package (release 11.5 for Windows) was used for all statistical analysis.

\section{Results}

\section{Effects of RSBF on water quality}

Addition of the flocculant mixture rapidly decreased the $\mathrm{pH}$ value (Fig. 2a), which reached a low of about 4.1 in all three treatments. A gradually increasing $\mathrm{pH}$ value was then observed until day 20 , reaching $\mathrm{pH}$ of 5.8 in the $\mathrm{RSBF}_{35}$ 
treatment, 6.2 in the $\mathrm{RSBF}_{25}$, and 7.1 in the $\mathrm{RSBF}_{15}$ treatments. The $\mathrm{pH}$ value in the control enclosures was about 7.0 , which was significantly higher than those in the $\mathrm{RSBF}_{35}$ treatment $(p<0.05$, ANOVA).

Secchi depth in the control was below $2 \mathrm{~m}$ throughout the experiment (Fig. 2b). However, an increased water transparency was observed in the RSBF treatments from the eighth day, peaking at $5 \mathrm{~m}$ on day 12 . While high water transparency continued until day 32 in the $\mathrm{RSBF}_{35}$ treatment.
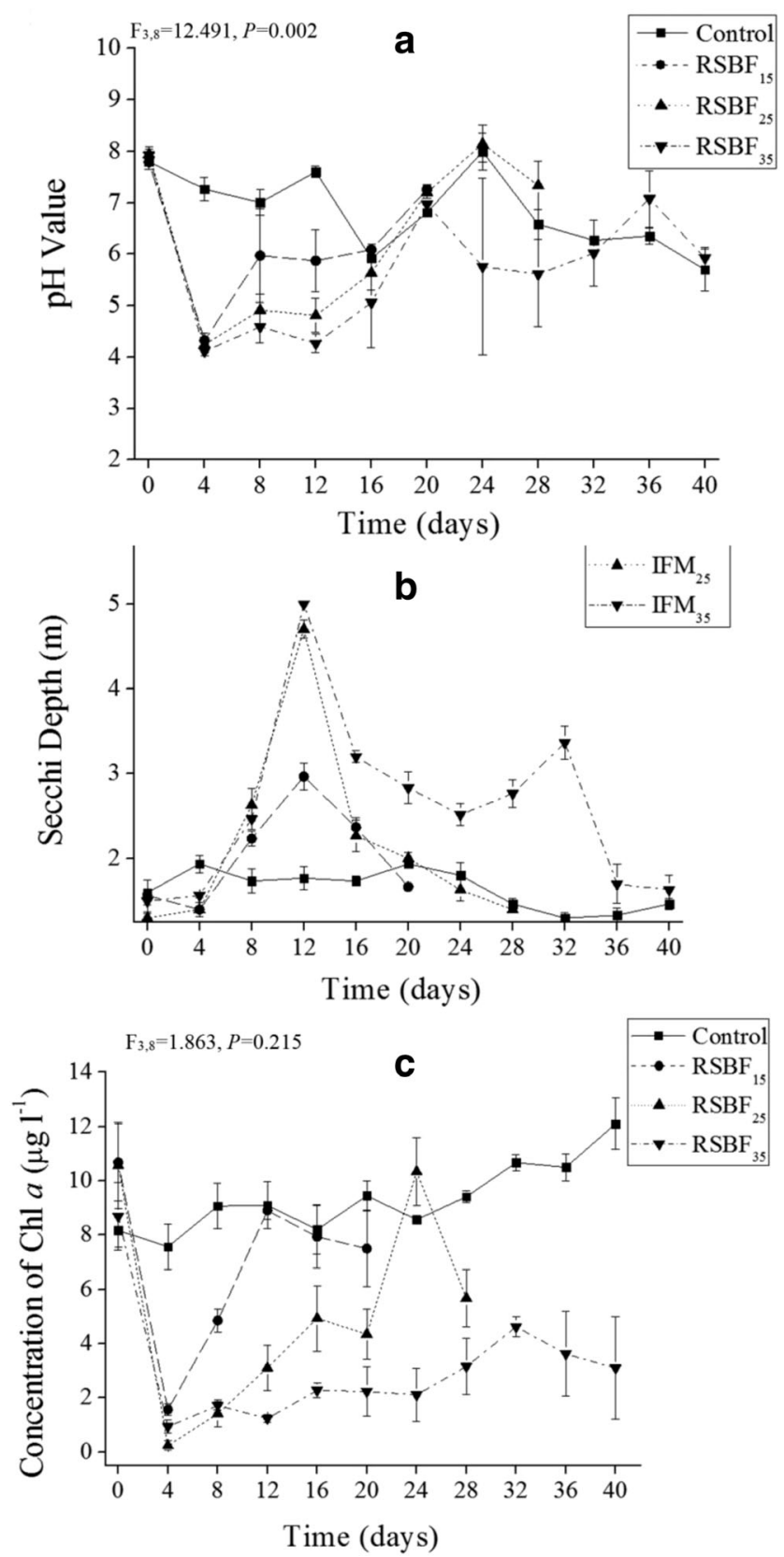

Fig. 2 Dynamics of $\mathrm{pH}$ value (a), SD (b), and concentration of chlorophyll $a(\mathbf{c})$ in three treatments. Error bar indicates standard deviation
Chlorophyll $a$ declined rapidly in the first 4 days in the RSBF treatments (Fig. 2c), but it recovered later. Chlorophyll $a$ concentration in the $\mathrm{RSBF}_{15}$ treatment recovered to a level similar to that in the control after 12 days. It took $\mathrm{RSBF}_{25} 24$ days to reach the same level as that in the control. The Chlorophyll $a$ concentration in the $\mathrm{RSBF}_{35}$ treatment always remained at a relatively low level until the end of the experiment.

Total nitrogen (TN), nitrate, ammonia, total phosphorus (TP), and soluble reactive phosphorus (SRP) declined significantly in the three treatments in the first week after RSBF was added compared with initial values (Fig. 3). Concentration of SRP was too low to be detected out by our instrument.

\section{Removal of phytoplankton and cyanobacteria}

At the beginning of the experiment, about 30 phytoplankton species were identified from all enclosures; these belonged to cyanobacteria, Chlorophyta, Bacillariophyta, Pyrrophyta, and Euglenophyta. Cyanobacterial species such as Microcystis spp. and Anabaena spp. predominated in the phytoplankton community, followed by filamentous Cylindrospermopsis spp., Limnothrix spp., and some Chlorophyta species, including Staurastrum gracile, Staurastrum dejectum, Tetraedron minimum, Scenedesmus quadricauda, and Quadrigula chodatii.

Cyanobacteria biomass in the control enclosures contributed to more than $70 \%$ of the total phytoplankton biomass except on the day 32, when Cosmarium spp. (Chlorophyta) dominated (Fig. 4a). Microcystis spp. and Anabaena spp. were dominant in the controls throughout the experimental period, while filamentous species such as Pseudoanabaena spp., Cylindrospermopsis spp., and Limnothrix spp. comprised only a very small proportion (Fig. 5a).

Biomass of Microcystis spp., Anabaena flos-aquae, and other filamentous species declined markedly in the three treatments in the first 12 days after RSBF was added $(p<0.05$, ANOVA. Fig. 5). In the $\mathrm{RSBF}_{35}$ treatment, phytoplankton biomass was almost completely removed, and only few algal cells were found, until day 28. More than $95 \%$ of cyanobacteria were removed in the experimental period (Fig. $4 \mathrm{~b})$. Towards the end of the experiment, cyanobacteria and Chlorophyta began to predominate, followed by diatoms. Chlorophyta biomass increased faster than others, and contributed more than $50 \%$ of the total biomass. Dominance of cyanobacteria was below $30 \%$, although phytoplankton biomass remained low (Fig. 4b). Average removal rate of Microcystis spp., Anabaena spp., and other filamentous species was 99,96 , and $52 \%$, respectively.

More than $80 \%$ of cyanobacteria was removed in the $\mathrm{RSBF}_{25}$ treatment (Fig. 4c). Phytoplankton biomass recovered on day 12, when cyanobacteria, Chlorophyta, and Bacillariophyta co-dominated (Fig. 4c). The dominance of 

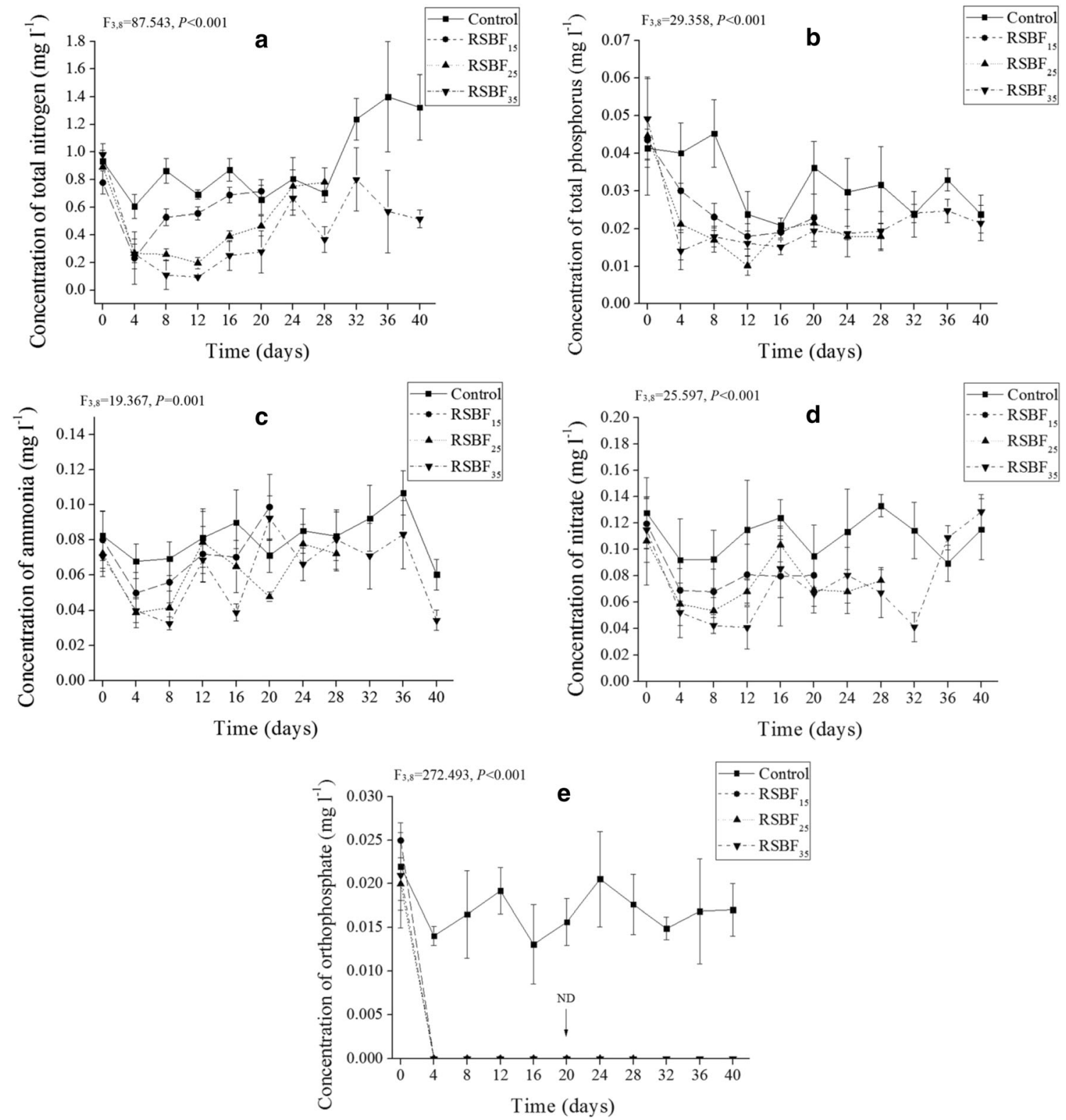

Fig. 3 Dynamics of nutrients concentration. a Total nitrogen. b Total phosphorus. c Ammonia. d Nitrate. e Orthophosphate. Error bar indicates standard deviation

cyanobacteria was less than $40 \%$. Average removal rate of Microcystis spp., Anabaena spp. and other filamentous species was 91,90 , and $47 \%$, respectively.

In the $\mathrm{RSBF}_{15}$ treatment, removal rate for cyanobacteria was about 40\% (Fig. 4d). From day 12 until the end of the experiment, cyanobacteria exclusively dominated the phytoplankton assemblage again (Fig. 4d), with Microcystis spp. and Anabaena spp. having recovered quickly at the end of period. The removal rate was $67 \%$ for Microcystis, $55 \%$ for Anabaena and $43 \%$ for the other filamentous cyanobacteria.

There was a linear relationship between $\mathrm{pH}$ value and biomass of cyanobacteria $\left(R^{2}=0.45, p<0.001\right.$; Fig. 6$)$, with the equation: Biomass $=0.0223 \times \mathrm{pH}-0.085$. Variation in the percent of cyanobacteria biomass in phytoplankton was independent of $\mathrm{pH}\left(R^{2}=8 \times 10^{-6} ; p>0.05\right)$.

\section{Effects of RSBF on zooplankton community}

About 22 zooplankton species were identified in all enclosures. The most common rotifers species were Keratella cochlearis, Brachionus forficula, Polyarthra vulgaris, Trichocerca cylindrica, and Filinia opoliensis. For Cladocera, Bosmina longirostris and Bosminopsis deitersi were the common species. The Copepoda were dominated by Thermocyclops taihokuensis, Heliodiaptomus serratus and their copepodites, and nauplii. 

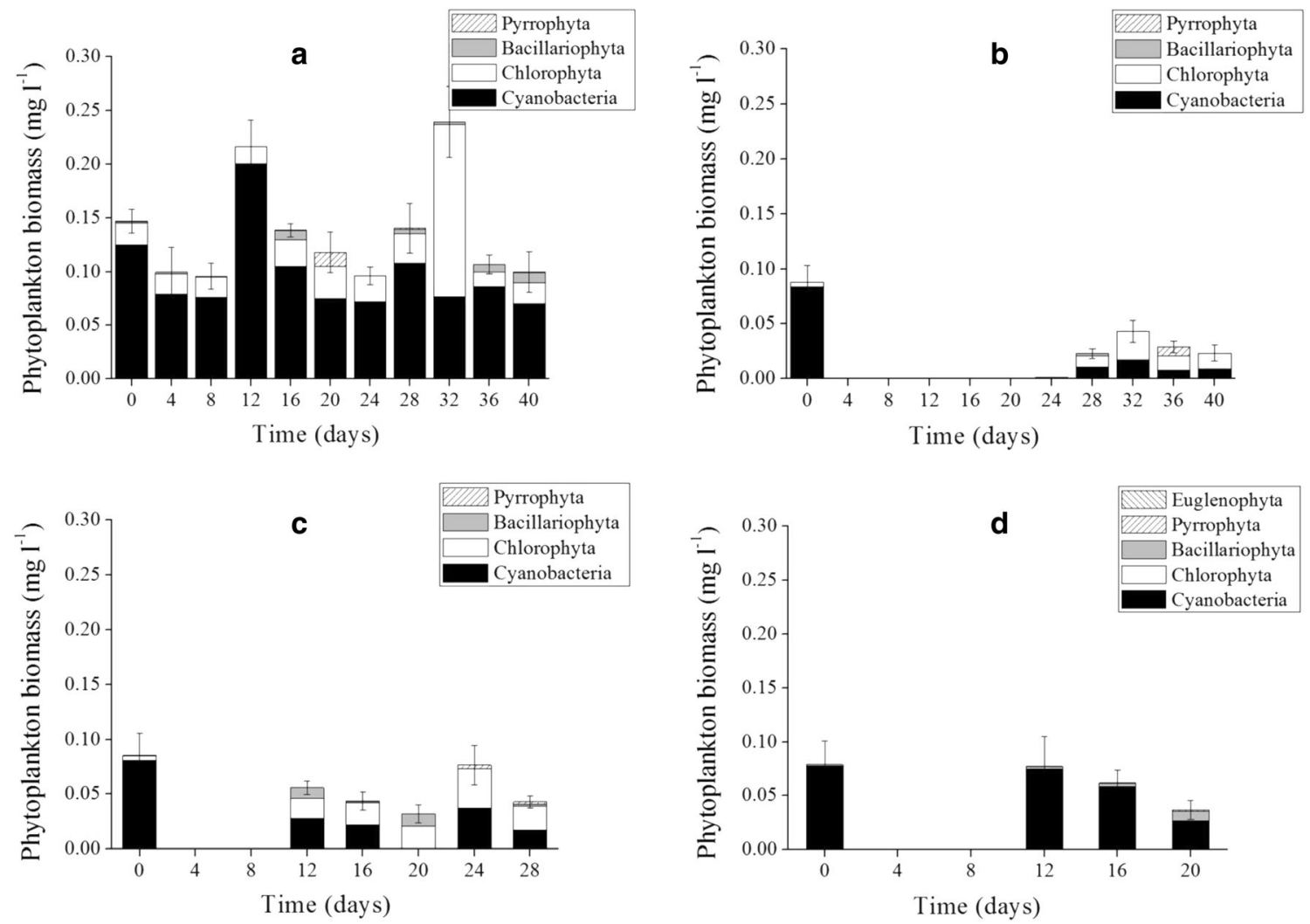

Fig. 4 Variation in phytoplankton biomass under four concentrations of RSBF. a Control. $\operatorname{RSBF}_{35}(\mathbf{b}) \cdot \operatorname{RSBF}_{25}(\mathbf{c}) . \operatorname{RSBF}_{15}(\mathbf{d}) . \mathrm{Error}$ bar indicates standard deviation

Copepods dominated the zooplankton assemblage in all experimental enclosures at the beginning of the experiment. Rotifer density in the three treatments quickly declined to less than two individuals per liter (Fig. 7a). Most rotier species disappeared by day 20, including Anuraeopsis fissa, Brachionus angularis, B. calyciflorus, Keratella tropica, Trichocerca stylata, T. rousseleti, T. pusilla, Collothecidae pelagica, and Hexarthridae mira. Recovery of rotifers in the treatments was very slow.

Cladocera, which were dominated by Bosmina longirostris and Bosminopsis deitersi Richard, was significantly affected by $\mathrm{RSBF}_{25}$ and $\mathrm{RSBF}_{35}$ (Fig. 8a). Although Thermocyclops taihokuensis was the dominant copepod species, the community biomass comprised mainly copepodites and nauplii (> $60 \%$, Fig. $8 \mathrm{~b}$ ). The effect of the flocculant mixture on Copepoda was similar to that on Cladocera. Copepods and Cladocera recovered faster than Rotifers under RSBF treatments, but species composition remained unchanged (Fig. 7).

\section{Discussion}

\section{Removal of cyanobacteria by RSBF}

Our experiment indicated that $\mathrm{RSFB}_{25}$ and $\mathrm{RSFB}_{35}$ can effectively remove Microcystis spp. and Anabaena spp.
Flocculation of similar clays has been practiced for mitigating harmful algal blooms (Sengco and Anderson 2004). For example, using modified clay in Lake Taihu in China, Pan et al. (2011) showed that $99 \%$ of the cells in a cyanobacterial bloom were removed after only $16 \mathrm{~h}$. The present study showed that $\mathrm{RSBF}_{25}$ and $\mathrm{RSBF}_{35}$ are capable of removing more than $95 \%$ of cyanobacteria within 4 days, especially for Microcystis spp. and Anabaena spp., which are the causing species for most of the blooms in China.

Teixeira et al. (2010) reported that the main coagulation mechanism of flocculating cyanobacterial cells by clay was due to charge neutralization. In the presence of an electrolyte, algal cells form aggregates with clay particles (Avnimelech et al. 1982). Both size and fractal dimension of flocculants were the most important parameters influencing removal efficiency (Han and Kim 2001). Stickiness on the surface of some cyanobacterial cells showed a significant positive correlation with the amount of extracellular uronic acids, which would play an important role in aggregation through the formation of cation bridges (Verspagen et al. 2006). Our results showed that RSBF is more efficient for Microcystis spp. and Anabaena spp. removal than for the other filamentous species such as Cylindrospermopsis spp. and Limnothrix spp. Both Microcystis spp. and Anabaena spp. secrete a layer of mucilage that could be useful in algal aggregation. Moreover, spherical cells of these two species could be bound more 

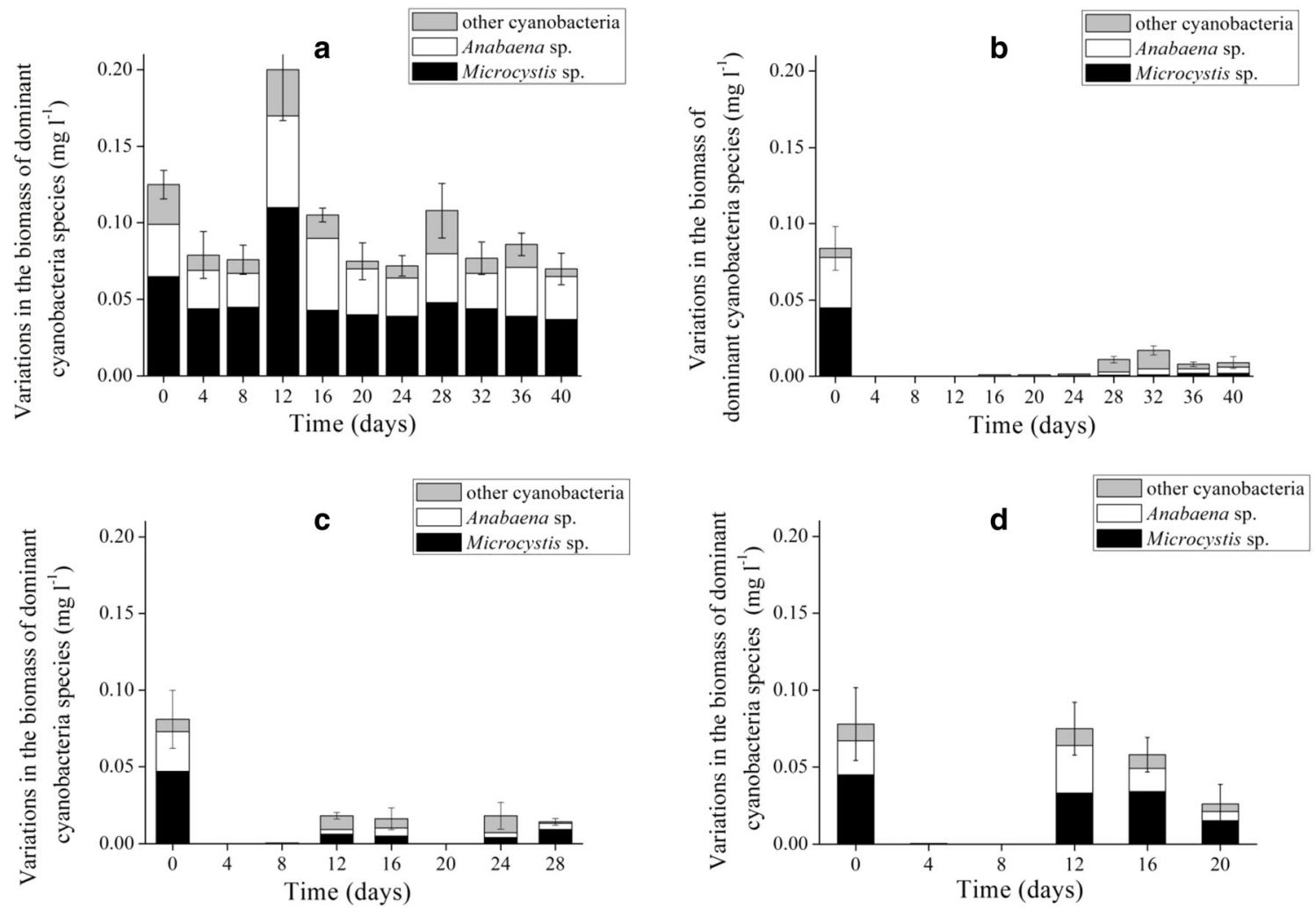

Fig. 5 Variation in the biomass of dominant species under four concentrations of RSBF. a Control. Treated with $\operatorname{RSBF}_{35}(\mathbf{b}), \mathrm{RSBF}_{25}(\mathbf{c}), \mathrm{and} \mathrm{RSBF}_{15}$ (d). Error bar indicates standard deviation

easily by the flocculants than do filamentous species. Chitosan is a linear polysaccharide composed of randomly distributed $\beta$-(1-4)-linked D-glucosamine and N-acetyl-D-glucosamine, and has the ability to bridge between individual flocs. Addition of chitosan may improve flocculation (Lertsutthiwong et al. 2009).

Flocculants such as ferric chloride are considered friendly flocculants that neither damage the structure of cyanobacterial cells nor cause acute release of cyanotoxins from the cells (Chow et al. 1998). Peterson et al. (1995) found that cell

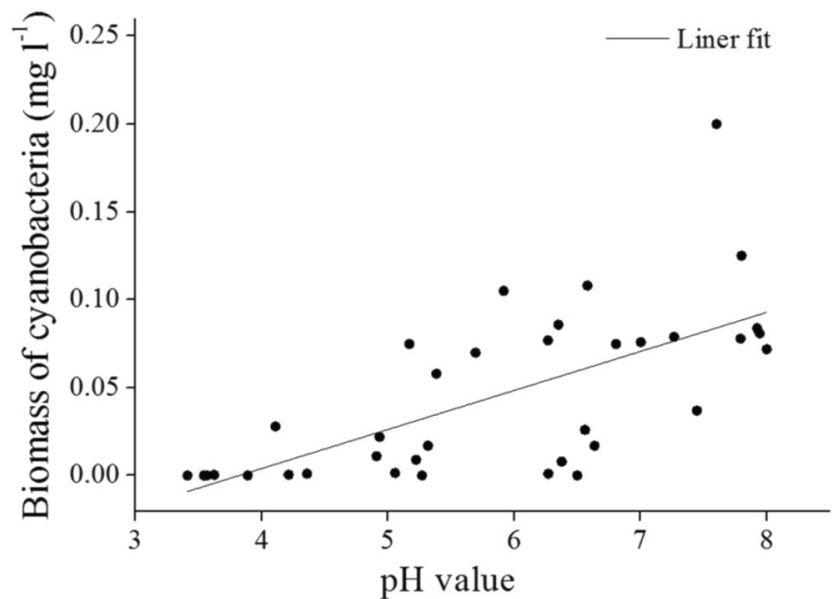

Fig. 6 Relationship between $\mathrm{pH}$ value and biomass of cyanobacteria: Biomass $=0.0223 \times \mathrm{pH}-0.085$ membrane of Aphanizomenon flos-aquae could not lysis under $25 \mathrm{mg} \mathrm{l}^{-1}$ of $\mathrm{FeCl}_{3}$. Furthermore, ferrate could remove cyanobacterial peptide toxins effectively from eutrophic waters (Yuan et al. 2002). In our experiment, cyanobacterial cells were flocculated and settled into the sediment in a short time (within 4 days). Cyanotoxins would be degraded quickly at the water-sediment interface (Chen et al. 2008).

\section{Recovering time of cyanobacteria}

Phytoplankton community structure is related to the trophic state (Aizaki et al. 1986; Reynolds et al. 2000; Padisák et al. 2009), and change in nutrient concentration has a consequential impact on phytoplankton community. When available nutrients are depleted by flocculation (Sridhar et al. 1988; Aguilar et al. 2002), phytoplankton abundance, biomass, and chlorophyll $a$ decline (Reynolds 2006). High light and nutrient availability favor the growth of Microcystis spp. and Anabaena spp. and reinforce their advantages for competition with other species (Havens et al. 1998; Nalewajko and Murphy 2001). Filamentous cyanobacteria such as Cylindrospermopsis spp. and Limnothrix spp. adapt to low light and low nutrient concentration (Isvánovics et al. 2000; Sinha et al. 2012). In our experiment, almost all cyanobacterial populations decreased rapidly in the first few days, and the trend of recovery depends on the dosage of 

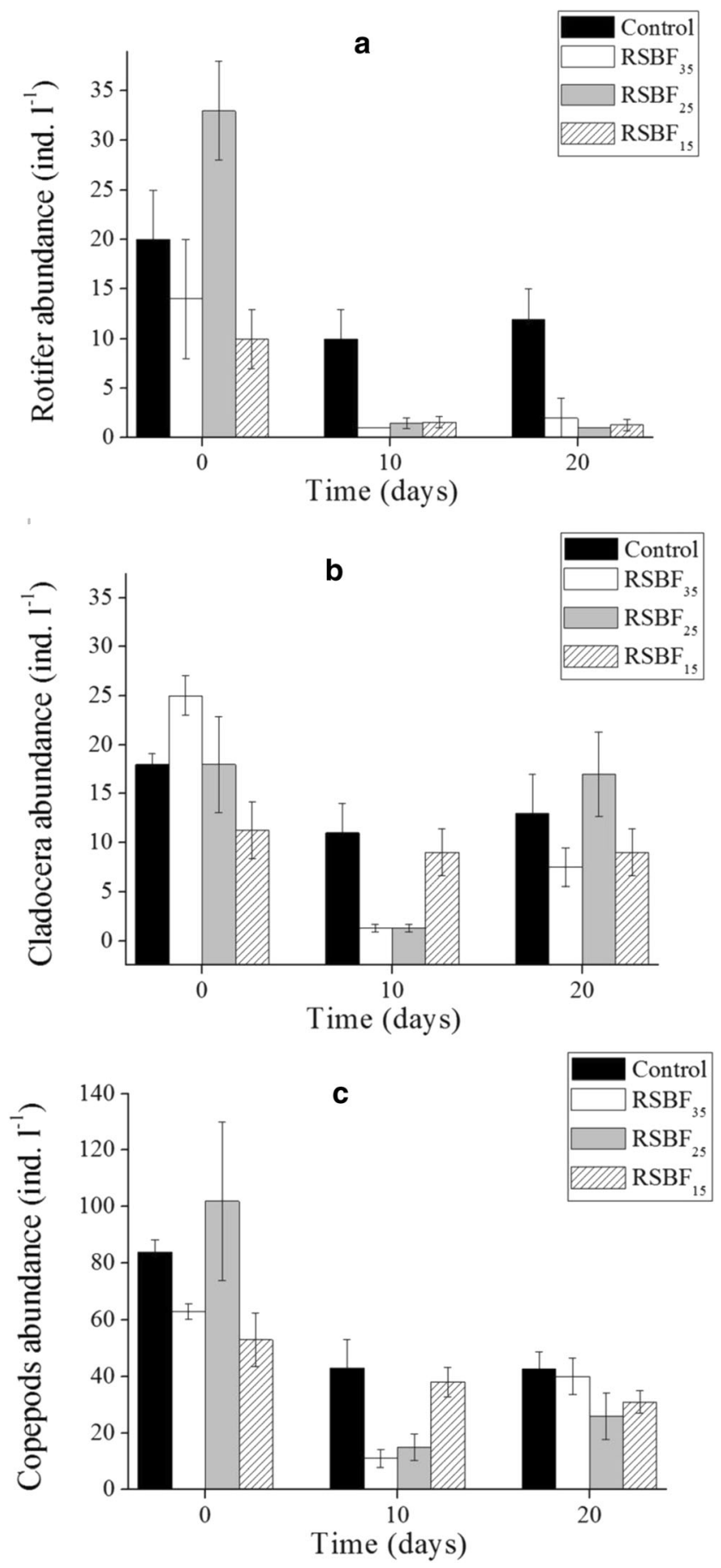

Fig. 7 Dynamics of zooplankton abundance for Rotifera (a), Cladocera (b), and Copepoda (c). Error bar indicates standard deviation

RSBF. For example, in the $\mathrm{RSBF}_{35}$ treatment, phytoplankton did not recover until the 28th day, and the dominant species was replaced by species belonging to Chlorophyta. $\mathrm{RSBF}_{25}$ treatment affected cyanobacteria recovery on day 12 but cyanobacteria were no longer the only dominant group. Microcystis spp. and Anabaena spp. biomass in $\mathrm{RSBF}_{15}$ recovered close to the control group on day 12 but cyanobacteria once again dominated the phytoplankton community.
Cyanobacteria usually prefer alkaline environments and will lose their competition advantage in acid water (Kupriyanova et al. 2011). In the treatment enclosures with RSBF, $\mathrm{pH}$ values showed a gradient in the order: $\mathrm{RSBF}_{15}>$ $\mathrm{RSBF}_{25}>\mathrm{RSBF}_{35}$. Recovery cyanobacterial biomass in the phytoplankton community corresponded to the gradient. $\mathrm{pH}$ value may control the recovering time of cyanobacteria.

\section{Effects of RSBF on water quality}

In the present study, $\mathrm{pH}$ rapidly decreased to below four in the three treatments. This is attributed to $\mathrm{Fe}^{3+}$ hydrolysis, in which hydrogen ion increases with $\mathrm{Fe}^{3+}$ occurrence (Sunda and Huntsman 2003; Gálvez et al. 2008). Low pH tends to reduce the competitive advantage of cyanobacteria equipped with $\mathrm{CO}_{2}$ concentration means (Thoms et al. 2001). Iron has the ability to bind with phosphorus (Kleeberg et al. 2013). Our experiment showed that prepared flocculant with iron and chitosan can effectively reduce $\mathrm{TP}, \mathrm{TN}$, as well as chlorophyll $a$. The optimal condition for iron to bind with phosphate in
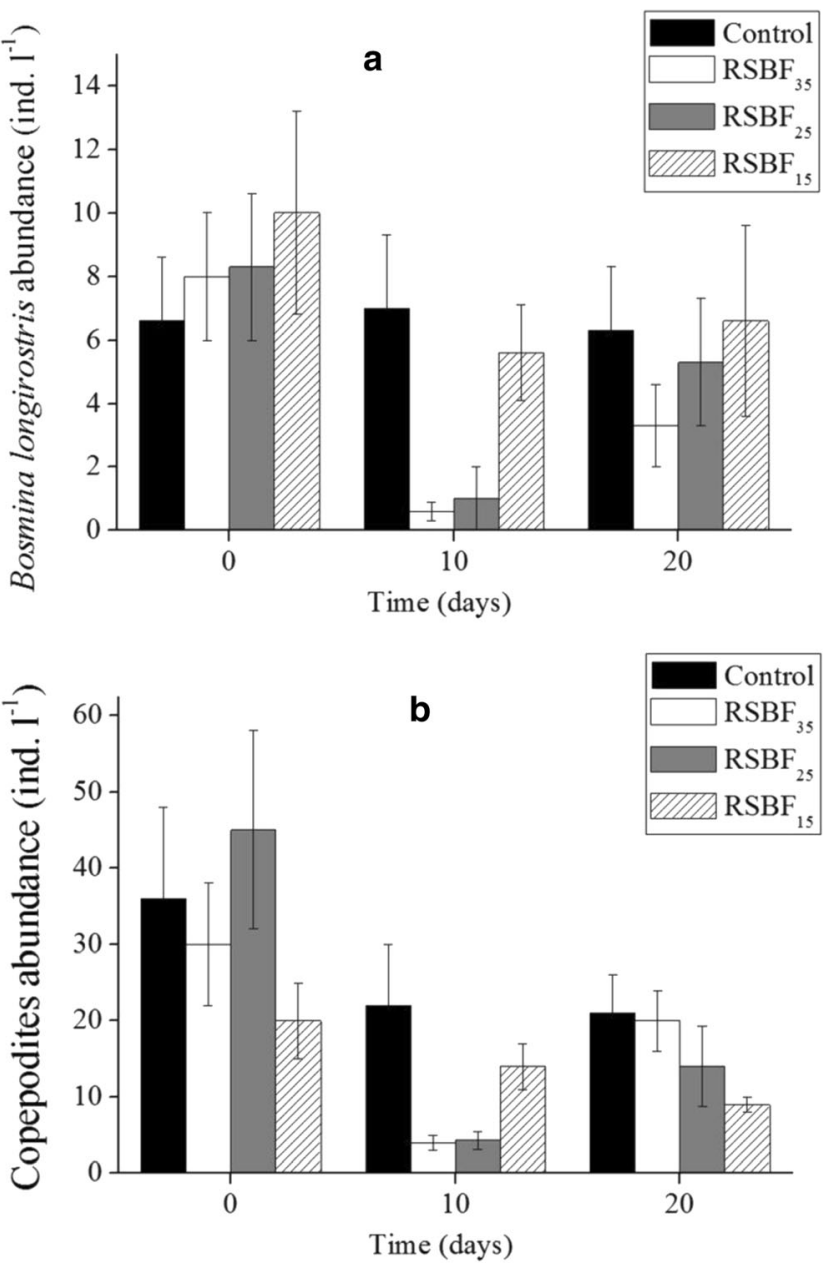

Fig. 8 Dynamics of zooplankton abundance for Bosmina longirostris (a) and Copepodites (b). Error bar indicates standard deviation 
flocculants with $\mathrm{pH}$ of between 5 and 7 (Cooke et al. 1993). Yuan et al. (2009) found that phosphorus sorption rates of $\mathrm{LaCl}_{3}$-modified clays were all higher than $90 \%$ in $\mathrm{pH}$ of 4 8 , with a maximum of $97 \%$ at $\mathrm{pH} 5$. Phosphate removal by kaolinite also depends on $\mathrm{pH}$, with maximum phosphate removal occurring at low $\mathrm{pH}$ of 3-5. In our experiment, TP, SRP, and also TN decreased significantly within 4 days, when pH was about 4 (Fig. 2a).

Reservoirs in southern China usually experience an obvious thermal stratification in the dry season (Xiao et al. 2011). The settled flocs are difficult to be resuspended up into the water column, and nutrient-flocculated organic matters (including algae) at the bottom hardly supports cyanobacterial growth in the water column. Moreover, if RSBF is taken as a method to improve water quality in the long run, high concentration of red soil might contribute to isolate sediments from the overlying water like a thin blanket, and would inhibit the release of phosphorus by putting a ceiling on the sediment.

\section{Effects of RSBF on zooplankton}

Toxicity of flocculation on zooplankton has been studied in laboratory and field experiments (Lewis et al. 2003; Seo et al. 2008). The $\mathrm{EC}_{50}$ of modified clay on the population growth of rotifer B. calyciflorus was calculated to be $0.15 \mathrm{~g}$ Phoslock ${ }^{\circledR}$ (van Oosterhout and Lürling 2013). Leachates of modified clay showed low toxicity to Daphnia dubia under $24.5 \mathrm{~g}$ clay/L, while Lanthanum addition was chronically toxic to Daphnia magna (Stauber 2000). Lürling and Tolman (2010) also found that low concentration of Phoslock modified clay has little effect on Daphnia. In our experiment, rotifers were rapidly reduced by $\mathrm{RSBF}$ to less than twp individuals per liter under the three RSBF treatments. $\mathrm{RSBF}_{25}$ and $\mathrm{RSBF}_{35}$ significantly reduced the abundance of cladocerans and copepods, but $\mathrm{RSBF}_{15}$ had less influence on the two zooplankton. High acidification can result in marked decrease in zooplankton biomass, abundance, and even species number (Geelen and Leuven 1986; Fischer et al. 2001; Vandysh 2002). Zooplankton species differ in their acid tolerance (Havens et al. 1993; Fischer et al. 2001). Rotifers have a very short life cycle, allowing them to be more sensitive to environmental factors than cladocerans and copepods (Kalff 2002).

Flocculants cause an abrupt perturbation on chemical and biological variables, which directly or indirectly influence zooplankton abundance and community structure (Urabe 1990; Seda and Devetter 2000; Gliwicz et al. 2010). For instance, zooplankton abundance will decrease with nutrient reduction that corresponds with food resource (Seda and Devetter 2000; Kalff 2002). Zooplankton prefers to graze edible-sized particles $(<30 \mu \mathrm{m})$ (Kalff 2002). In the control enclosures, phytoplankton was always dominated by indigestible cyanobacteria. After being treated with RSBF, the enclosures were almost devoid of phytoplankton, and although cyanobacteria and Chlorophyta somewhat recovered in the later period of the experiment, they were at a low biomass. Therefore, we speculate that food availability is changed after adding the flocculant, but it is difficult to be quantitatively evaluated, also see van Oosterhout and Lürling (2011) for Daphnia.

\section{Conclusions}

The new modified flocculant with iron and chitosan can effectively remove cyanobacteria, especially for spherical cell species such as Microcystis spp. and Anabaena spp. Cyanobacteria will slowly recover according to the flocculant dosage. The red soil-based flocculant has a significant effect on zooplankton, but copepods and cladocera recovered fast. For its easy preparation, low impact on crustaceans and low cost, we suggest that the red soil-based flocculant is an effective material in removing cyanobacteria biomass for urgent management in tropical reservoirs for drinking water supply.

Acknowledgments We thank Dr. Ken Chan from Australia for his reading and commenting.

Author contributions Peng L. and Han B.P. designed the experiments, Liu L. and Chen X.K. performed the experiments, Lei L.M. analyzed the data, and Han B.P contributed materials and analysis tools. Peng L. and Han B.P. wrote the paper.

Funding Information This research was supported by the grant (No. 31070416) from National Science Foundation of China (NSFC), the Science and Technology Project for Application of Guangdong Province, China (No. 2015B020235007), and the project (2009-22) from Water Resource Department of Guangdong Province for warning and control of cyanobacterial blooms in small reservoirs and the grant from Guangdong Province for leading talent scientists to Dr. Henri Dumont.

\section{Compliance with ethical standards}

Conflict of interest The authors declare that they have no conflict of interest.

Open Access This article is distributed under the terms of the Creative Commons Attribution 4.0 International License (http:// creativecommons.org/licenses/by/4.0/), which permits unrestricted use, distribution, and reproduction in any medium, provided you give appropriate credit to the original author(s) and the source, provide a link to the Creative Commons license, and indicate if changes were made.

\section{References}

Aguilar MI, Saez J, Llorens M, Soler A, Ortuno JF (2002) Nutrient removal and sludge production in the coagulation-flocculation process. Water Res 36:2910-2919

Aizaki M, Otsuki A, Kawai T (1986) Relationship between nutrient loading and phytoplankton standing crop in outdoor experimental ponds with continuous flow systems. Water Res 20(7):859-863 
Akeprathumchai S, Han BB, Wickramasinghe SR, Carlson JO, Czermak P, Preiss K (2004) Murine leukemia virus clearance by flocculation and microfiltration. Biotechnol Bioeng 88:880-889

Anderson DM (2009) Approaches to monitoring, control and management of harmful algal blooms (HABs). Ocean Coast Manag 52:342347

Archambault MC, Bricelj VM, Grant J, Anderson DM (2004) Effects of suspended and sedimented clays on juvenile hard clams, Mercenaria mercenaria, within the context of harmful algal bloom mitigation. Mar Biol 144:553-565

Avnimelech Y, Troeger BW, Reed LW (1982) Mutual flocculation of algae and clay: evidence and implications. Science 216(4541):6365

Beaulieu SE, Sengco MR, Anderson DM (2005) Using clay to control harmful algal blooms: deposition and resuspension of clay/algal flocs. Harmful Algae 4:123-138

Boustany RG (2003) A pre-vegetated mat technique for the restoration of submersed aquatic vegetation. Ecol Restor 21(2):87-94

Cai YF, Kong FX, Shi LM, Yu Y (2012) Spatial heterogeneity of cyanobacterial communities and genetic variation of Microcystis populations within large, shallow eutrophic lakes (Lake Taihu and Lake Chaohu, China). J Environ Sci (China) 24(10):1832-1842

Chen W, Song LR, Peng L, Wan N, Zhang XM, Gan NQ (2008) Reduction in microcystin concentrations in large and shallow lakes: water and sediment-interface contributions. Water Res 42:763-773

China National Standards (1987a) Water quality-determination of ammonium-Nessler's reagent clormetric method. GB:58-72

China National Standards (1987b) Water quality-determination of nitratespectrophotometric method with phenol disulfonic acid. GB:73-77

China National Standards (1989a) Water quality-determination of total nitrogen-alkaline potassium persulfate digestion-UV spectrophotometric method. GB:192-195

China National Standards (1989b) Water quality-determination of total phosphorus-ammonium molybdate spectrophotometric method. GB: $188-191$

Chorus I, Bartram J (1999) Toxic cyanobacteria in water: a guide to their public health consequences, monitoring and management. St Edmundsbury Press, Bury St Edmunds

Chow CWK, House J, Velzeboer RMA, Drikas M, Burch MD, Steffensen DA (1998) The effect of ferric chloride flocculation on cyanobacterial cells. Water Res 32:808-814

Codd GA (2000) Cyanobacterial toxins, the perception of water quality, and the prioritisation of eutrophication control. Ecol Eng 16:51-60

Combes A, Dellinger M, Cadel-six S, Amand S, Comte K (2013) Ciliate Nassula sp. grazing on a microcystin-producing cyanobacterium (Planktothrix agardhii): impact on cell growth and in the microcystin fractions. Aquat Toxicol 126:435-441

Cooke GD, Welch EB, Martin AB, Fulmer DG, Hyde JB, Schrieve GD (1993) Effectiveness of $\mathrm{Al}, \mathrm{Ca}$, and $\mathrm{Fe}$ salts for control of internal phosphorus loading in shallow and deep lakes. Hydrobiologia 253: 323-335

Dash P, Silwal S, Ikenga JO, Pinckney JL, Arslan Z, Lizotte RE (2015) Water quality of four major lakes in Mississippi, USA impacts on human and aquatic ecosystem health. Water 7:4999-5030

de Figueiredo DR, Azeiteiro UM, Esteves SM, Gonçalves FJM, Pereira MJ (2004) Rapid communication microcystin-producing blooms-a serious global public health issue. Ecotoxicol Environ Saf 59:151163

Fischer JM, Klug JL, Ives AR, Frost TM (2001) Ecological history affects zooplankton community responses to acidification. Ecology 82: 2984-3000

Gálvez JL, Dufour J, Negro C, López-Mateos F (2008) Hydrolysis of iron and chromium fluorides: mechanism and kinetics. J Hazard Mater 154:135-145

Geelen JFM, Leuven RSEW (1986) Impact of acidification on phytoplankton and zooplankton communities. Experientia 42:486-494
Gliwicz ZM, Szymanska E, Wrzosek D (2010) Body size distribution in Daphnia populations as an effect of prey selectivity by planktivorous fish. Hydrobiologia 643:5-19

Han MY, Kim W (2001) A theoretical consideration of algae removal with clays. Microchem J 68:157-161

Havens KE, Yan ND, Keller W (1993) Lake acidification: effects on crustacean zooplankton populations. Environ Sci Technol 27: $1621-1624$

Havens KE, Phlips EJ, Cichra MF, Li B (1998) Light availability as a possible regulator of cyanobacteria species composition in a shallow subtropical lake. Freshw Biol 39:547-556

Hillebrand H, Dürselen CD, Kirschtel D, Pollingher U, Zohary T (1999) Biovolume calculation for pelagic and benthic microalgae. J Phycol 35:403-424

Hrudey S, Burch M, Drikas M, Gregory R (1999) Remedial measures. In: Chorus I, Bartram J (eds) Toxic cyanobacteria in water: a guide to their public health consequences, monitoring and management. St Edmundsbury Press, Bury St Edmunds, pp 267-275

Hunt RJ, Matveev VF (2005) The effects of nutrients and zooplankton community structure on phytoplankton growth in a subtropical Australian reservoir: an enclosure study. Limnologica 35:90-101

Isvánovics V, Shafik HM, Présing M, Juhos S (2000) Growth and phosphate uptake kinetics of the cyanobacterium, Cylindrospermopsis raciborskii (Cyanophyceae) in through flow cultures. Freshw Biol 43:257-275

Jeppesen E, Søndergaard M, Liu ZW (2017) Lake restoration and management in a climate change perspective: an introduction. Water 9: $1-8$

Jeune AHL, Charpin M, Deluchat V, Briand JF, Lenain JF, Baudu M, Amblard C (2006) Effect of copper sulphate treatment on natural phytoplanktonic communities. Aquat Toxicol 80:267-280

Ji RP, Lu XW, Li XN, Pu YP (2009) Biological degradation of algae and microcystins by microbial enrichment on artificial media. Ecol Eng 35(11): 1584-1588

Kalff J (2002) Limnology: inland water ecosystems. Prentice Hall, New York

Kleeberg A, Herzog C, Hupfer M (2013) Redox sensitivity of iron in phosphorus binding does not impede lake restoration. Water Res 47:1491-1502

Korovchinsky NM (1992) Sididae \& Holopediidae (Crustacea: Daphniiformes). SPB Academic Publishing, The Hague

Koste W (1978) Rotatoria. Die Rädertiere Mitteleuropas, vol 2. Gebrüder Borntraeger

Kupriyanova EV, Sinetova MA, Markelova AG, Allakhverdiev SI, Los DA, Pronina NA (2011) Extracellular ß-class carbonic anhydrase of the alkaliphilic cyanobacterium Microcoleus chthonoplastes. J Photochem Photobiol B 103:78-86

Lawton LA, Cornish BJPA, Macdonald AWR (1998) Removal of cyanobacterial toxins (microcystins) and cyanobacteria 1 cells from drinking water using domestic water filters. Water Res 32(3):633638

Lee YJ, Choi JK, Kim EK, Youn SH, Yang EJ (2008) Field experiments on mitigation of harmful algal blooms using a Sophorolipid-Yellow clay mixture and effects on marine plankton. Harmful Algae 7:154 162

Lei LM, Lin SJ, Hu R (2012) Cyanobacteria and cyanotoxins in reservoirs of South China. In: Han BP, Liu ZW (eds) Tropical and subtropical reservoir limnology in China. Springer Press, Berlin, pp $109-122$

Lertsutthiwong P, Sutti S, Powtongsook S (2009) Optimization of chitosan flocculation for phytoplankton removal in shrimp culture ponds original research article. Aquac Eng 41(3):188-193

Lewis MA, Dantin DD, Walker CC, Kurtz JC, Greene RM (2003) Toxicity of clay flocculation of the toxic dinoflagellate, Karenia brevis, to estuarine invertebrates and fish. Harmful Algae 2:235-246 
Lin SJ, He LJ, Huang PS, Han BP (2005) Comparison and improvement on the extraction method for chlorophyll a in phytoplankton. Ecol Sci 24(1):9-11 (in Chinese)

Lindholm T, Eriksson JE, Meriluoto JAO (1989) Toxic cyanobacteria and water quality problems-examples from a eutrophic lake on Åland, South West Finland original research article. Water Res 23:481-486

Liu JF (2016) Algal removal and water improvement by $\mathrm{FeCl}_{3}$-modified red soils in eutrophic water bodies (D). Jinan University (in Chinese)

Liu GF, Fan CX, Zhong JC, Zhang L, Ding SM, Yan SH, Han SQ (2010) Using hexadecyl trimethyl ammonium bromide (CTAB) modified clays to clean the Microcystis aeruginosa blooms in Lake Taihu, China. Harmful Algae 9:413-418

Lund JWG, Klipling C, Le Cren ED (1958) The inverted microscope method of estimating algal numbers and the statistical basis of estimating by counting. Hydrobiologia 11:143-170

Lürling M, Faassen EJ (2012) Controlling toxic cyanobacteria: effects of dredging and phosphorus-binding clay on cyanobacteria and microcystins. Water Res 46:1447-1459

Lürling M, Tolman Y (2010) Effects of lanthanum and lanthanummodified clay on growth, survival and reproduction of Daphnia magna. Water Res 44:309-319

Mitrovic SM, Hardwick L, Dorani F (2011) Use of flow management to mitigate cyanobacterial blooms in the lower Darling River, Australia. J Plankton Res 33(2):229-241

Nalewajko C, Murphy TP (2001) Effects of temperature, and availability of nitrogen and phosphorus on the abundance of Anabaena and Microcystis in Lake Biwa, Japan: an experimental approach. Limnology 2:45-48

Newcombe G, House J, Ho L, Baker P, Burch M (2010) Management strategies for cyanobacteria (blue-green Algae): a guide for water utilities. Research Report 74. Adelaide, SA, Australia, pp 50-55

Nishi L, Vieira AMS, Vieira MF, Bongiovani M, Camacho FP, Bergamasco R (2012) Hybrid process of coagulation/flocculation with Moringa oleifera followed by ultrafiltration to remove Microcystis sp. cells from water supply. Procedia Eng 42:865-872

O'Neil JM, Davis TW, Burford MA, Gobler CJ (2012) The rise of harmful cyanobacteria blooms: the potential roles of eutrophication and climate change. Harmful Algae 14:313-334

Padisák J, Crossetti LO, Naselli-Flores L (2009) Use and misuse in the application of the phytoplankton functional classification: a critical review with updates. Hydrobiologia 621:1-19

Paerl HW, Hall NS, Calandrino ES (2011) Controlling harmful cyanobacterial blooms in a world experiencing anthropogenic and climatic-induced change. Sci Total Environ 409(10):1739-1745

Pan G, Zhang MM, Chen H, Zou H, Yan H (2006) Removal of cyanobacterial blooms in Taihu Lake using local soils. I. Equilibrium and kinetic screening on the flocculation of Microcystis aeruginosa using commercially available clays and minerals. Environ Pollut 141(2):195-200

Pan G, Yang B, Wang D, Chen H, Tian BH, Zhang ML, Yuan XZ, Chen J (2011) In-lake algal bloom removal and submerged vegetation restoration using modified local soils. Ecol Eng 37:302-308

Peterson HG, Hrudey SE, Cantin IA, Perley TR, Kenefick SL (1995) Physiological toxicity, cell membrane damage and the release of dissolved organic carbon and geosmin by Aphanizomenon flosaquae after exposure to water treatment chemicals. Water Res 29(6):1515-1523

Qin BQ (2002) Approaches to mechanisms and control of eutrophication of shallow lakes in the middle and lower reaches of the Yangze River. J Lake Sci 14(3):193-202

Qin BQ, Zhu GW, Gao G, Zhang YL, Li W, Paerl HW, Carmichael WW (2010) A drinking water crisis in Lake Taihu, China: linkage to climatic variability and Lake management. Environ Manag 45: $105-112$
Rajasekhar P, Fan L, Nguyen T, Roddick FA (2012) A review of the use of sonication to control cyanobacterial blooms. Water Res 46:43194329

Reynolds CS (2006) The ecology of phytoplankton. Cambridge University Press, London

Reynolds CS, Dokulil M, Padisák J (2000) Understanding the assembly of phytoplankton in relation to the trophic spectrum: where are we now? Hydrobiologia 424:147-152

Robb M, Greenop B, Goss Z, Douglas G, Adeney J (2003) Application o f Phoslock ${ }^{\mathrm{TM}}$, an innovative phosphorus binding clay, to two Western Australian waterways: preliminary findings. Hydrobiologia 494:237-243

Seda J, Devetter M (2000) Zooplankton community structure along a trophic gradient in a canyon-shaped dam reservoir. J Plankton Res 22:1829-1840

Sengco MR, Anderson DM (2004) Controlling harmful algal blooms through clay flocculation. J Eukaryot Microbiol 51(2):169-172

Sengco MR, Li AS, Tugend K, Kulis D, Anderson DM (2001) Removal of red- and brown-tide cells using clay flocculation. I. Laboratory culture experiments with Gymnodinium breve and Aureococcus anophagefferens. Mar Ecol Prog Ser 210:41-53

Seo KS, Lee CK, Park YT, Lee Y (2008) Effect of yellow clay on respiration and phytoplankton uptake of bivalves. Fish Sci 74:120-127

Shen CJ, Song DX (1979) Calanoida. In: Shen CJ (ed) Freshwater Copepoda. Science Press, Beijing

Sinha R, Pearson LA, Davis TW, Burford MA, Orr PT, Neilan BA (2012) Increased incidence of $C$. raciborskii in temperate zones-is climate change responsible? Water Res 46(5):1408-1419

Sridhar P, Namasivayam C, Prabhakaran G (1988) Algae flocculation in reservoir water. Biotechnol Bioeng 32:345-347

Stauber JL (2000) Toxicity testing of modified clay leachates using freshwater organisms. Centre for Advanced Analytical Chemistry, pp 1-17

Sunda W, Huntsman S (2003) Effect of pH, light, and temperature on FeEDTA chelation and Fe hydrolysis in seawater. Mar Chem 84:35-47

Teixeira MR, Rosa MJ (2006) Integration of dissolved gas flotation and nanofiltration for M. aeruginosa and associated microcystins removal. Water Res 40:3612-3620

Teixeira MR, Sousa V, Rosa MJ (2010) Investigating dissolved air flotation performance with cyanobacterial cells and filaments. Water Res 44:3337-3344

Thoms S, Pahlow M, Wolf-Gladrow AA (2001) Model of the carbon concentrating mechanism in chloroplasts of eukaryotic algae. J Theor Biol 208:295-313

Urabe J (1990) Stable horizontal variation in the zooplankton community structure of a reservoir maintained by predation and competition. Limnol Oceanogr 35:1703-1717

van Apeldoorn ME, van Egmond HP, Speijers GJA, Bakker GJI (2007) Toxins of cyanobacteria. Mol Nutr Food Res 51:7-60

van Oosterhout F, Lürling M (2011) Effects of the novel 'Flock \& Lock' lake restoration technique on Daphnia in Lake Rauwbraken (The Netherlands). J Plankton Res 33(2):255-263

van Oosterhout F, Lürling M (2013) The effect of phosphorus binding clay (Phoslock®) in mitigating cyanobacterial nuisance: a laboratory study on the effects on water quality variables and plankton. Hydrobiologia 710:265-277

Vandamme D, Foubert I, Muylaert K (2013) Flocculation as a low-cost method for harvesting microalgae for bulk biomass production. Trends Biotechnol 31(4):233-239

Vandysh OI (2002) Effect of acidification on zooplankton communities of small lakes in mountain tundra. Water Res 29:602-609

Verspagen JMH, Visser PM, Huisman J (2006) Aggregation with clay causes sedimentation of the buoyant cyanobacteria Microcystis spp. Aquat Microb Ecol 44:165-174

Wang S, Qian X, Han BP, Luo LC, Hamilton DP (2012) Effects of local climate and hydrological conditions on the thermal regime of a 
reservoir at Tropic of Cancer, in southern China. Water Res 46(8): 2591-2604

Xiao LJ, Han BP, Lin QQ, Lei LM (2007) Usage of flocculation in emergent control of algal bloom in drinking water supplying reservoir. Environ Sci 28(10):2192-2197 (in Chinese)

Xiao LJ, Wang T, Hu R, Han BP, Wang S, Qian X, Padisák J (2011) Succession of phytoplankton functional groups regulated by monsoonal hydrology in a large canyon-shaped reservoir. Water Res 45:5099-5109
Xu JH, Xu RS, Miao L, Xia B, Zhu ZY (2006) Contents and distributions of trace elements in red soil of Guangdong Province. Chin J Soil Sci 37(5):964-968 (in Chinese)

Yuan BL, Qu JH, Fu ML (2002) Removal of cyanobacterial microcystinLR by ferrate oxidation-coagulation. Toxicon 40:1129-1134

Yuan XZ, Pan G, Chen H, Tian BH (2009) Phosphorus fixation in lake sediments using $\mathrm{LaCl}_{3}$-modified clays. Ecol Eng 35:1599-1602 